UDC: 796:658

DOI: https://doi.org/10.26661/hst-2020-5-82-11

\title{
MANAGEMENT OF HUMAN RESOURCES IN A SPORTS ORGANISATION FROM THE POINT OF VIEW OF EMPLOYEES
}

\author{
(C) LEKAVIČIUS, TOMAS \\ Lithuanian Sports University (Kaunas, Lithuania) \\ E-mail: tlekavicius@yahoo.com, \\ ORCID iD https://orcid.org/0000-0002-8863-6868 \\ LT87122 Telšiai, Turgaus square 12- 4, Lithuania
}

\begin{abstract}
The relevance of this study. Human resource management in sports organization helps achieving the objectives of the organization, realizing the mission and tasks in optimal conditions, and using the individuals for the benefit of the organization. In sports organization, human resource management is related not only with the assurance of effective workforce, but also with sports achievements of the recipients of sports services, glorification of sports organization. It is important that human resource management is integrated into the strategic plans of the organization. The significance of human resource management of sports organizations to activity results is analyzed widely enough, but the changes of the time determine the changes of human resource management which are displayed through the need of new managerial competences and modern management methods in sports organizations. The aim of the study - after discussing the essence of human resource management and determining factors, to establish the directions of human resource management development in sports and recreation centre in the point of view of the employees. Research methods: analysis and synthesis of scientific literature, questionnaire, statistical analysis of the data. The result of the study. Strategic management of organizations integrates the strategic objectives of human resource management the content of which covers the selection of human resources, corresponding to the necessary competences, purposeful competence training and instruction, motivating assessment, leadership of the heads, team work creation and communication. This guarantees efficient management of sports organization when achieving the objectives of the organization and implementation of the organization's role. The results indicated that there is a need for human resource management development in the organization. The biggest gaps were established in the areas of training, development and work payment, and deficiencies were identified in motivation system.
\end{abstract}

Keywords: sports organization, human resources, management.

Introduction. Sport is a widely spread phenomenon, being able to increase human energy and concentrate financial, material resources which can be difficulty compared with the resources of other areas of social life. Management of sports organizations is influenced and determined by the correspondence and requirements, rising from documents issued by international organizations which have authorisations in this area. Organizational development is basically considered the strategy on purpose of increasing organisational effectiveness when establishing the changes in all areas of organization's activity. A sports organization is $<<$ a social subject acting in sports industry and directing its activity towards the objective, with consciously structured activity system and quite easily established limit $>>$ [14]. According to Byers et al. [4]. sports organizations "objective is oriented towards consciously structured activity system and quite easily established limit; it is a social formation which was created 
by the individuals and which are supervised for a specific purpose prepare, train sportsmen; it is a united team which collaborates when achieving the agreed objective or tasks". Management of sports organizations cannot be created not using the methods which could help going deeper into rational usage of human resources, encouragement of human creativity, optimisation and standardised decision making as well as management of all functions. Effective management methods, intended for using tools and instruments, economic factor, increase of workforce, more efficient sports activities, achievement of objectives and right decision making are the problems which can arise in organization, greater integration in sports organization is what increases satisfaction with work.

Research methodology. The objective of the research is to establish the factors determining human resource management in the point of view of the employees of sports and recreation centre. The aim of the study - after discussing the essence of human resource management and determining factors, to establish the directions of human resource management development in sports and recreation centre in the point of view of the employees. Research object - human resource management. Research tasks: to describe the theoretical conception of human resource management and the factors conditioning the human resource management; to analyse the specific nature of human resource management in sports organisations; to establish the direction of development of human resource management in sports and recreation centre in the point of view of the employees. Research problem is raised with the question of how human resource management is assessed in sports and recreation centre in the point of view of the employees and what areas should be developed on purpose of achieving suitable system of human resource management. Research strategy and logics. Quantitative research strategy is used for the accomplishment of the research, a questionnaire was prepared for that purpose. Verbal permission was received from the head of the institution for performing the questioning of employees. The questioning was performed in the sports and recreation centre by distributing paper printed questionnaires. The research instrument was formed of 64 closetype questions and 1 open-type question which covers seven scales of the research: selection and employment; adaptation; appreciation of employees; work payment; training and development; work safety and hygienic requirements; motivation; formation of favourable climate and work relations. Nine questions are given in the questionnaire to establish the directions of development of the centre's human resource management and five demographic questions are presented as the Research instrument, prepared with reference to the theoretical and empirical insights of Lobanova (2015a, 2015b), Surujlal and Mafini (2011), Zeng and $\mathrm{Hu}$, (2017), Iconomescu et al., (2014), 
Gradinaru (2015), etc. The statements, used in the Research instrument, were assessed in Likert scale from 1 to 5 or (respectively, 1 - totally disagree, 2 disagree, 3 - no opinion, 4 - agree, 5 totally agree). The questionnaire was performed in written, using printed questionnaires

\section{Main Material}

Coordination of strategic management and human resource management methods helps the organisation adapting to new competitiveness conditions, using the advantages provided by modern science and technologies, and achieving long-term balanced corporative objectives [11]. According to Juodeikaite, Fominienès (2016), main elements of the strategy of human resource management are formed of: planning of the need for human resources; wage and employees' motivation; assessment of human resources and the environment as well as employee training and qualification raising. All these elements have influence on the changes of human resources; they have to be assessed on purpose of managing them. Human resource management is an integrated process which cannot act separately and has to agree with the organization's strategy, and has to assess the environmental factors. This has to be a regular process on purpose of guaranteeing effective implementation of human resource management functions, at the same time guaranteeing the implementation of the organisation's objectives and creating long-term competitive advantage of the whole organization [21].

Academic literature analyses the peculiarities of sports organisation management [18] and significance of the development of this management to the quality of services [26], influence of professionalism of personnel management on the results of sports organisations' activity [30], significance of strategic planning in the activity of sports organizations [32], influence of institutional changes on the activity of sports organizations [13], the influence of gender differences in sports organizations' management [2]. According to Covell et al. (2007), sports organizations exist to perform the tasks which can be performed only in the way of collaboration, and sports management is responsible for the activity and success of these organizations. The area of sports management exists as a response to the increasing demand of the consumers for sports products and services, which reach billions in the whole world every year. As it could be expected, in several last decades, sport has had influence on various social, cultural and economic aspects [31].

Leisure sport has become the biggest source of income for sports organizations not taking the sector, to which it belongs, into consideration: public, private profit or non-profit organization. Increasing interest in sport increased the value of income. According to Brindescu (2009), previously, specialists and researchers, thinking that sales in the market is not related with sports consumption, believe that the income 
increased because of sport. In present environment, sports organizations have to be managed like any other business organizations which cover the management of many business functions, including human resources. Billing (1985) states that human resources make the main resource of any organizations. According to Slack (1997), the efficiency of sports organization is greatly influenced by how it uses its human resources. The function of human resource management in sports organizations today is more integrated and oriented towards the strategy. This corresponds to Chadwick's (2009) argument that sports management and structuring has to pay more attention to advanced, active and strategic management. According to Sobreiro et al. (2018), the assumptions are created in the strategy which should reflect the sports organization and the environment surrounding it. It is important to foresee the difficulties which can arise when implementing the strategy, and to define the necessary resources (including financial and human). It would be purposeful to provide the action plan when achieving the planned results and referring to the following factors [32]:

- Organization's mission and vision.

- Establishment of strategic objectives.

- The parties concerned which are able to affect or which can be affected when implementing the strategy.

- Business

possibilities, peculiarity of organization's activity, processes, personnel's skills, information technologies.

- Assessment of concern and objectives of the parties concerned: to establish the problems or dissatisfaction of the parties concerned with the organization.

- Establishment of improvement priorities: referring to the analysis of existing resources, assessment, anticipating the priorities of organizational activity improvement.

- Definition of the action plan: based on assessment and analysis, establishment of improvement directions, new business possibilities.

These steps form specific cycle of methods the duration of which differs depending on the management of senior hierarchy level.

Ivancevich (1998) states that it would be difficult to imagine sports organizations which aim at keeping efficiency without effective human resource programmes as the role of human resource management is really important when guaranteeing that sports organization stays and prospers.

According to Chelladurai (1999), there are three different groups of people which form human resources in sports organizations, i.e. paid professional employees, volunteers and customers. The head leader performs the decisive role in modern sports world by providing his/her knowledge and possibilities for achieving organizational objectives, achieving quality and satisfying the needs of members and market. Professional sports trainer is among paid professional employees. A professional sports trainer provides an important service - training. This 
service cannot be provided if no customers participate, i.e. sportsmen or players. As the survival of a sports organization depends on its customers, it is very important to effectively manage the trainers. Goslin (1996) indicates that professional trainers should be properly prepared for providing sport services otherwise sport can lose possible effect of social stabilizer. According to Judge \& Piccolo (2004), O`Reilly, et. al. (2010), the management has to efficiently react to new needs of organizations: innovations, cultural variety, workbased knowledge, communication and work groups. Work groups play the main role in organizations, and management is necessary on purpose of guaranteeing the efficiency of these teams.

According to Saiz (2010), because of their peculiarities and variety, modern organizations are favourable for exploring the models of leadership. Speaking more specifically, globalization, new technologies, communication and economic as well as social tendencies challenge the organizations having new managerial roles and functions [3]. Because of the need of solving new challenges in globalized world, the leaders have to accept a complex role which covers the coordination of continuation and innovations, based on strong integration practice of social values, principles of ethics and groups of specialists of different areas. Compared with regular traditional leadership, there emerged many more dynamic leadership models. For example, transformation model which shows positive correlation not only between different individual variables of the leader (ethics, emotional management, knowledge formation, etc.), but also with the results in organizational level (better results, bigger satisfaction of the team).

Day et al. (2004) state that team guidance can be understood in two ways. First, leadership is understood as attributes (abilities and behaviour), which are brought into the team by the members, for example, charisma, etc. Attributes have influence on group's processes and results. Second, leadership is understood as the results of group processes (group learning), facilitating the adaptation of work team and performance in various stages of development. Both attitudes are necessary on purpose of understanding the leadership of the team.

Redman, Mathews (1998) state that sports organizations aim at improving the quality of provided services by using various methods of human resource management. Human resource management plays a more important role in sports organisations as products are immaterial and are not tangible.

Ivancevich (1998) states that on purpose of growing, prospering and surviving, sports organizations have to optimizing the return of the investments of all resources, especially financial and human resources. Thus the directors and heads of human resources understand that it is necessary to take care of own employees. Therefore human resource management of professional sports 
trainers is as important as any other management function.

Billing (1985) states that the problems of human management often arise because of changeability of human nature and behaviour, therefore human resource management is especially important when achieving organizational success. Sports organizations experience regularly changing activity climate (Moore, 2008). Many questions, related to the activity of sports organizations, include human resource management. On purpose of understanding the dynamics of human resource management and human resource management in sports organizations, especially when speaking about professional sports trainers, it is necessary to understand the role of professional sports trainers in a sports organization. On purpose of keeping professional sports trainers, sports organizations have to manage them effectively. According to Armstrong (1992), any success, which can be achieved by a sports organization, depends on the competence of its human resources. It is important to pay attention to the uniqueness of work of a professional sports trainer in the context of sport instructing. Such factors as resources (machinery, equipment, assistants and sportsmen), which are available to the trainer, external factors and the ability of the trainer make influence on the trainer's productivity. Therefore professional sports trainer management has to be assessed differently than the management of the employees of other sports organizations. In sports organisations, human resources also acquire a unique meaning. This is a resource that synchronizes all sports organization activities. These are people who work hard to get the best possible result for management, athletes, sponsors and spectators [33]. According to Chadwick (2009), as sports keeps developing in the whole world, discussions about how to control sport that it keeps its basic and most attractive features, will still be important. Many things depend on the most important resources processed by the sports organizations - human resources if sports organizations aim at gaining competitive advantage in sports industry. It can be little expected that sports organizations will survive in a more competitive environment if they ignore worrisome questions related to people. Demographic changes, the variety of workforce, change of management and couching skill requirements as well as governmental legal acts change the nature of sports organizations.

Competition is one of the main factors determining the increase of quality in the services provided by sports organizations. In the course of time, various methods were used in leading sports organizations which were varied and developed using science and technologies. These methods are processes or measures used for achieving the objectives. Even if management methods are usually adopted from the activity area of business organizations, they are adapted to sports organizations so that their application is achieved [10]. As Dajnoki, Szabada and Baba (2018) 
point out, the interaction of sports activities with the business area is becoming more intense. The ability of the sports sector to generate profits shows that sport is becoming an important sector of the economy. Sport is becoming more and more commercial, and in this context, competitiveness aspects are becoming more and more important. In a competitive sport sector, leadership development is of particular importance. Strong leadership in sports organisations can become a strong source of competitive advantage. For this reason, it is important to focus on leadership and invest in its development [17]. And while the importance of human resources management in sports organisations is not in doubt, these processes are not always implemented effectively enough [34,25], are human resources management gaps that hamper the achievement of maximum efficiency in this area.

Results.

Organizations' employees can be motivated not only by work payment, but also by respectful relations with the head, colleagues, acceptability of organization's values, communication and collaboration in the organization, harmony of the collectives, career possibilities. On purpose of achieving efficiency, it is important that organization's motivation system works effectively, motivation measures are suitable, the criteria of selection of motivation measures are clear and known to all employees. A separate block in the questionnaire was intended for the assessment of these aspects. The descriptive statistics of the statements of employee motivation block is presented in Table 1.

Table 1. Descriptive statistics of the statements of employee motivation block

\begin{tabular}{|l|l|l|l|l|l|}
\hline \multicolumn{1}{|c|}{ Statements } & $\mathbf{N}$ & $\mathbf{M i n}$ & $\mathbf{M a x}$ & $\mathbf{M}$ & SD \\
\hline There prevail respectful relations with the head & 40 & 4.00 & 5.00 & 4.43 & 0.50 \\
\hline There prevail respectful relations with the colleagues & 40 & 3.00 & 5.00 & 4.18 & 0.59 \\
\hline The employees follow the values declared by the organization & 40 & 3.00 & 5.00 & 3.98 & 0.66 \\
\hline $\begin{array}{l}\text { Communication and collaboration can be felt among the } \\
\text { employees, harmonious collective is formed }\end{array}$ & 40 & 2.00 & 5.00 & 3.98 & 0.73 \\
\hline $\begin{array}{l}\text { The system of employee encouragement and motivation is } \\
\text { effective in the organization }\end{array}$ & 40 & 2.00 & 5.00 & 3.55 & 0.90 \\
\hline $\begin{array}{l}\text { The criteria on motivation measures are clear and known to all } \\
\text { employees }\end{array}$ & 40 & 2.00 & 5.00 & 3.55 & 0.96 \\
\hline There is the possibility of career seeking & 40 & 2.00 & 5.00 & 3.60 & 0.90 \\
\hline Motivation measures are suitable & 40 & 2.00 & 5.00 & 3.45 & 0.85 \\
\hline
\end{tabular}

It was established during the research that there are especially favourable employee motivation aspects, but also there such aspects the potential of development of which really exists. Especially high average point was given by the respondents to the domination of respectful relations with the head $(M=4.43)$. Quite favourable assessment was also given to the respectfulness of the relations with the colleagues $(M=4.18)$. The lowest average point was given by the respondents to the appropriateness of 
motivation measures $(M=3.45)$. Such research results allow stating that the motivation measures, applied in Telšiai sports and recreation centre, only are partially in harmony with the expectations and needs of the employees of this centre. This can be clearly seen in the distribution of the research participants according to the agreement to the latter statement (see Table 2). Despite the fact that even 45.00 per cent of the research participants agreed with the statement that motivation measures are suitable, only 7.50 per cent of respondents were completely sure about that, and almost the third of the sample had doubts (32.50 per cent). When assessing the distribution of respondents according to the agreement with the statements of employee motivation block, it can be seen that respectfulness of the relations with the head is one of the strongest features of the organization. No participants of the research indicated that disagree with the aforementioned statement or have doubts about it. And even 42.50 per cent of the participants of the research were completely sure about strong relations with the head.

Table 2. Distribution of respondents according to the agreement with the statements of employee motivation block, respondent per cent.

\begin{tabular}{|l|l|l|l|l|l|l|}
\hline \multicolumn{1}{|c|}{ Statements } & $\begin{array}{c}\text { Completely } \\
\text { disagree }\end{array}$ & Disagree & $\begin{array}{c}\text { Neither } \\
\text { agree, nor } \\
\text { disagree }\end{array}$ & Agree & $\begin{array}{c}\text { Completely } \\
\text { agree }\end{array}$ & $\begin{array}{c}\text { In } \\
\text { total }\end{array}$ \\
\hline $\begin{array}{l}\text { There prevail respectful } \\
\text { relations with the head }\end{array}$ & 0.00 & 0.00 & 0.00 & 57.50 & 42.50 & 100.00 \\
\hline $\begin{array}{l}\text { There prevail respectful } \\
\text { relations with the } \\
\text { colleagues }\end{array}$ & 0.00 & 0.00 & 10.00 & 62.50 & 27.50 & 100.00 \\
\hline $\begin{array}{l}\text { Employees follow the } \\
\text { values declared by the } \\
\text { organization }\end{array}$ & 0.00 & 0.00 & 22.50 & 57.50 & 20.00 & 100.00 \\
\hline $\begin{array}{l}\text { Communication and } \\
\text { collaboration can be felt } \\
\text { among the employees, } \\
\text { harmonious collective is } \\
\text { formed }\end{array}$ & 0.00 & 2.50 & 20.00 & 55.00 & 22.50 & 100.00 \\
\hline $\begin{array}{l}\text { Employee encouragement } \\
\text { and motivation system is } \\
\text { effective in the } \\
\text { organization }\end{array}$ & 0.00 & 15.00 & 27.50 & 45.00 & 12.50 & 100.00 \\
\hline $\begin{array}{l}\text { Criteria of motivation } \\
\text { measures are clear and } \\
\text { known to all employees }\end{array}$ & 0,00 & 12.50 & 40.00 & 27.50 & 20.00 & 100.00 \\
\hline $\begin{array}{l}\text { There is the possibility of } \\
\text { career seeking }\end{array}$ & 0.00 & 12.50 & 30.00 & 42.50 & 15.00 & 100.00 \\
\hline $\begin{array}{l}\text { Motivation measures are } \\
\text { suitable }\end{array}$ & 0.00 & 15.00 & 32.50 & 45.00 & 7.50 & 100.00 \\
\hline
\end{tabular}

Most doubts for the employees were raised by the clarity of motivation measures and notoriety to all employees. Even 40.00 per cent of research participants when expressing their positions regarding these criteria 
selected the variant of the answer "neither agree, nor disagree". This means that insufficient clarity and notoriety of motivation measures make a gap which needs to be corrected on purpose of increasing the employees' motivation.

When assessing the employees' attitude towards the areas of human resource management, it was established that the evaluations of human resource management areas reach from 3.65 to 4.08 points. The worst average point was given to training and development activity and the highest average point was given to work safety and hygiene requirements.

Table 3. Descriptive statistics of assessments of human resource management areas

\begin{tabular}{|l|c|c|c|c|c|}
\hline \multicolumn{1}{|c|}{ Activities } & N & Min & Max & M & SD \\
\hline Employee selection and employment & 40 & 2.00 & 5.00 & 3.85 & 0.62 \\
\hline Employee adaptation & 40 & 3.00 & 5.00 & 3.80 & 0.69 \\
\hline Employee assessment & 40 & 3.00 & 5.00 & 3.75 & 0.63 \\
\hline Work payment & 40 & 2.00 & 5.00 & 3.70 & 0.72 \\
\hline Training and development & 40 & 3.00 & 5.00 & 3.65 & 0.58 \\
\hline Work safety and hygienic requirements & 40 & 3.00 & 5.00 & 4.08 & 0.69 \\
\hline Formation of favourable climate and work relations & 40 & 3.00 & 5.00 & 3.90 & 0.67 \\
\hline
\end{tabular}

The distribution of respondents according to activity assessments is presented in Table 4ю The research results show that more than half of respondents assess all human resource management activities in Telšiai sports and recreation centre really well. Only 10.00-27.50 per cent of respondents tend to assess these activities very well.

Table 4. Distribution of respondents according to the assessments of human resource management activities, respondent per cent

\begin{tabular}{|l|l|l|c|l|l|l|}
\hline Activities & $\begin{array}{l}\text { Very } \\
\text { bad }\end{array}$ & Bad & Satisfactorily & Good & $\begin{array}{l}\text { Very } \\
\text { well }\end{array}$ & $\begin{array}{l}\text { In } \\
\text { total }\end{array}$ \\
\hline Employee selection and employment & 0.00 & 2.50 & 20.00 & 67.50 & 10.00 & 100.00 \\
\hline Employee adaptation & 0.00 & 0.00 & 35.00 & 50.00 & 15.00 & 100.00 \\
\hline Employee assessment & 0.00 & 0.00 & 35.00 & 55.00 & 10.00 & 100.00 \\
\hline Work payment and hygienic & 0.00 & 5.00 & 30.00 & 55.00 & 10.00 & 100.00 \\
\hline Training and development and safety and & 0.00 & 0.00 & 40.00 & 55.00 & 5.00 & 100.00 \\
\hline $\begin{array}{l}\text { Work } \\
\text { requirements }\end{array}$ & 0.00 & 20.00 & 52.50 & 27.50 & 100.00 \\
\hline $\begin{array}{l}\text { Formation of favourable climate and } \\
\text { work relations }\end{array}$ & 0.00 & 27.50 & 55.00 & 17.50 & 100.00 \\
\hline
\end{tabular}

During the performance of the research, respondents were asked to indicate their satisfaction in the human resource activity performed in the organization. As the data, provided in the painting, show, the bigger part of respondents (67.50 per cent) is satisfied with the activity of human resource management performed in sport and recreation centre. 15,00 per cent of respondents were completely unsatisfied. Employees' satisfaction was restricted by certain problematic aspects for the elimination of which the participants of the research provided suggestions. 
During the research, suggestions were received to increase the work payment, pay more attention to training, qualification rising, to extend the adaptation period, to improve finance management, attract volunteers, encourage friendly support to each other in sports and recreation centre.

\section{Conclusions}

Strategic organization management integrates the strategic objectives of human resource management, the content of which covers the selection of human resources, corresponding to the necessary competences, purposeful education and training, motivating assessment, leadership of the heads, creation of team work and communication. On purpose of better organizing the management of human resources of sports organizations, they should prepare the strategy of human resources, and while implementing it, they have to motivate human resources, develop human resources through training and train the skills of human resource management. This guarantees efficient management of sports organization when achieving organizational objectives and implementing the organizational role.

Research results show that sports organizations have general human resource management laws. The activity of such organizations is based on all basic human resource management factors (personnel, work payment, employee qualification development, employee maintenance, work relations). Specific content of realization of these factors is exceptionally adapted to the needs of sports organization. Advanced human resource management practice, responding to the needs of sports organization, makes preconditions for the sports organization to achieve the highest activity results. The results indicated that there is a need for human resource management development in the organization.The biggest gaps were established in the areas of training, development and work payment, and deficiencies were identified in motivation system.

\section{REFERENCES}

1. Armstrong, M. (1992). Strategies for Human Resource Management: A Total Business Approach. London: Koran Page Ltd.

2. Anastasovski, I., Aleksovska, L., Naumovski, M. et al. (2017). New challenge - gender structure in the process of management in sports and sports organization impact from legal and economic aspects. Research in Physical Education, Sport and Health, Vol. 6, No. 2. 9-13.

3. Burke, R. J., Cooper, C. (2006). Leading in Turbulent Times. Oxford: Blackwell.

4. Byers, T., Parent, M., Slack, T. (2012). Key Concepts in Sport Management. London: Sage.

5. Billing, J. (1985). Personnel management: staff recruitment, selection and retention. In G. Lewis, H. Appenzeller (Eds.), Successful Sport Management (pp.165-179). Virginia: The Michie Company

6. Brindescu, S. (2009). Managementul organizatiilor sportive - studiu de caz la organizaţiile fotbalistice, teză de doctorat, UVT.

7. Day, D. V., Gron, P., Salas, E. (2004). Leadership capacity in teams. The Leadership Quaterly, 15, 857-880

8. Dajnoki, K., Szabados, G. N., Baba, E. B. (2018). A case study on human resource management practice of a sport organization. International Journal of Engineering and Management Sciences, 3(4). 410-425.

(C) Lekavičius Tomas, 2020 
9. Chadwick, S. (2009). From outside lane to inside track: Sport management research in the twenty-first century. Management Decision, 47 (1). 191-203.

10. Chelladurai, P. (1999). Human Resource Management in Sport and Recreation. IL: Human Kinetics.

11. Chlivickas, E., Papšienė, P., Papšys, A. (2009). Žmogiškieji ištekliai: strateginio valdymo aspektai. Verslas, vadyba, studijos 2009. Vilnius: Technika.

12. Covell D., Walker S., Siciliano J., Hess P. (2007). Managing sports organizations: responsibility for performance, 2nd ed. London: Elsevier.

13. Dimopoulou, S., Avgerinou, V., Samioti, S. E., et al. (2018). The Importance of Total Quality Management and Business Excellence in Sports Organizations - A Case Study in Olympic Athletic Center. Spiros Louis, Choregia, No. 14(2). 49-54.

14. Eksteen, E. (2014). Sport Organisation and Administration. UK: Bookboon.

15. Gradinaru, G. (2015). Management methods in sports performance. Annals of the "Constantin Brancusi" University of Targu Jiu, Economy Series, 6. 229-234.

16. Goslin, A. E. (1996). Human resource management as a fundamental aspect of sport development strategy in South African communities. Journal of Sport Management, 10. 207-217.

17. Frawley, S., Favaloro, D., Schulenkorf, N. (2017). Experience-based leadership development and professional sport organizations. Journal of Sport Management, 32(2), 123-134.

18. Iancu, D., Robescu, O., Istrate, C. et al. (2016). Management of Sports Organizations: Concepts, Skills, Knowledge. Valahian Journal of Economic Studies. Vol. 7 (21), Issue 3, pp. 75-82.

19. Ionescu, G. (2001). Management General. Bucaresti: Tribuna Economica.

20. Ivancevich, J. M. (1998). Human resource management. New York: Irwin/McGraw-Hill.

21. Juodeikaitė, M., Fominienè, A. (2016). Žmogiškųjų išteklių valdymo procesų pokyčių vertinimas: teorinis ir praktinis aspektas. Informacijos mokslai. 74. 25-37

22. Lobanova, L. (2015a). Žmogiškujų išteklių vadyba sanglaudos procesų Europos Sajungos kontekste. Daktaro disertacija. Vilnius: Technika.

23. Judge, T. A., Piccolo R. F. (2004). Transformational and transactional leadership: a metaanalytic test of their relative validity. Journal of Applied Psychology. 89(5). 755-768

24. Lobanova, L. (2015b). Žmogiškujų išteklių vadyba: metodai ir standartai. Viešasis administravimas. 3-4(47-48). 17-28.

25. Lower, L. M., Czekanski, W. A. (2019). Effective management of scarce resources: a case study of American collegiate sport clubs. Managing Sport and Leasure. 24(1-3). 119-140.

26. Molcut, A., Elvira, V., Flavius, N. (2015). Sports organizations management improvement: a survey analysis. Annals of Faculty of Economics, Vol. 1(1). 1019-1028.

27. O`Reilly, C., Caldwell, D., Chatman, J., Lapiz, M. \& Self, W. (2010). How leadership matters: The effects of leaders alignment on strategy implementation. The Leadership Quartely. 21(1). 104113.

28. Redman, T., Mathews, B. P. (1998). Service quality and human resource management. Personnel Review. 27(1). 57-77.

29. Saiz, G. (2010). Aprender a liderar. Paldos.

30. Schmidt, J. (2017). Professionalism in Management and Performance in Sports Organizations, pp. 87-99. [seen in October 2, 2020]. Internet approach: https://www.researchgate.net/publication/324765448_Professionalism_in_Management_and_Perform ance_in_Sports_Organizations Hall.

31. Snyder, E.E., Spreitzer, E.A. (1989) Social aspects of sport, 3rd Edition. New York : Prentice

32. Sobreiro, P.A., Santos-Rocha, R., Claudino, R. et al. (2018). Approach to management by processes in a sports department of a local government organization. Motricidade, Vol. 14, N. 2, pp. 79-94.

33. Surujlal, J. (2016). Managing human resources in sport: issues, challenges and possible remedies management and tourism: sport management and tourism. African Journal for Physical Activity and Health Sciences. 22(31). 760-776.

34. Zalaff, K., Hidayatullah, M. F., Kristyanto, A. (2017). Sports human resource management of sport development index in Padang, West Sumatra, Indonesia - evaluation studies of the availability of 
sports human resource management. European Journal of Physical Education and Sport Science. 3(3). 97-104.

35.Zeng, Q-X, Hu, L. (2017). A Study on Strategic Human Resource Management and Sports Organization Performance. 4th International Conference on Economics and Management (ICEM 2017).

\author{
ЛЯКАВИЧЮС, ТОМАС - магістрант програми Менеджмент туризму i спорту \\ Литовського університету спорту (Литва, Каунас) \\ E-mail: tlekavicius@yahoo.com \\ ORCID iD https://orcid.org/0000-0002-8863-6868
}

\title{
УПРАВЛІННЯ ЛЮДСЬКИМИ РЕСУРСАМИ В СПОРТИВНІЙ ОРГАНІЗАЦІЇ 3 ТОЧКИ ЗОРУ СПІВРОБІТНИКІВ
}

\begin{abstract}
Анотація. Актуальність даного дослідження. управління людськими ресурсами в спортивній організації допомагає досягти цілей організації, реалізувати місію і завдання в оптимальних умовах. У спортивній організації управління людськими ресурсами пов'язане не лише із забезпеченням ефективних кадрів, але із спортивними досягненнями адресатів спортивних послуг, уславленням спортивної організації. Важливо, щоб управління людськими ресурсами було інтегровано у стратегічні плани організації. Значення управління людськими ресурсами спортивних організацій аналізується досить широко, але зміни обставин визначають зміни в управлінні людськими ресурсами, які проявляються в необхідності нових управлінських компетенцій і сучасних методів управління в спортивних організаціях. Мета дослідження - обговоривши суть управління людськими ресурсами і визначальні чинники, визначити напрями розвитку управління людськими ресурсами в спортивно-оздоровчому центрі з точки зору співробітників. Методи дослідження : аналіз і узагальнення наукової літератури, анкетування, статистичний аналіз даних. Результат дослідження. Стратегічне управління організаціями об'єднує стратегічні цілі управління людськими ресурсами, зміст яких охоплює відбір людських ресурсів, що відповідають необхідним компетенціям, цілеспрямоване навчання і підвищення компетенцій, мотивуючу оцінку, лідерство керівників, створення командної роботи і комунікацію. Це гарантує ефективне управління спортивною організацією, досягши цілей організації і реалізації ролі організації. Результати засвідчили, що існує необхідність в розвитку управління людськими ресурсами в організації. Найбільші прогалини були виявлені в сферах навчання, підвищення кваліфікації і оплати праці, а також виявлені недоліки в системі мотивації.
\end{abstract}

Ключові слова: спортивна організація, людські ресурси, менеджмент.

ЛЯКАВИЧЮС, ТОМАС - магистрант программы менеджмент туризма и спорта Литовского университета спорта (Литва, Каунас)

E-mail: tlekavicius@yahoo.com

ORCID iD https://orcid.org/0000-0002-8863-6868

\section{УПРАВЛЕНИЕ ЛЮДСКИМИ РЕСУРСАМИ В СПОРТИВНОЙ ОРГАНИЗАЦИИ С ТОЧКИ ЗРЕНИЯ СОТРУДНИКОВ}

\section{Аннотация}

Актуальность данного исследования. Управление человеческими ресурсами в спортивной организации помогает достичь целей организации, реализовать миссию и задачи в оптимальных условиях. В спортивной организации управление человеческими ресурсами связано не только с обеспечением эффективных кадров, но и со спортивными достижениями получателей спортивных услуг, прославлением спортивной организации. Важно чтобы управление человеческими ресурсами было интегрированно в стратегические планы организации. Значение управления человеческими ресурсами спортивных организаций анализируется достаточно широко, но изменения обстоятельств определяют изменения в управлении человеческими ресурсами, которые проявляются в необходимости новых управленческих компетенций и современных методов управления в спортивных организациях. Цель исследования - обсудив сущность управления человеческими ресурсами и 
определяющие факторы, определить направления развития управления человеческими ресурсами в спортивно-оздоровительном центре с точки зрения сотрудников. Методы исследования: анализ и обобщение научной литературы, анкетирование, статистический анализ данных. Результат исследования. Стратегическое управление организациями объединяет стратегические цели управления человеческими ресурсами, содержание которых охватывает отбор человеческих ресурсов, соответствующих необходимым компетенциям, целенаправленное обучение и повышение компетенций, мотивирующую оценку, лидерство руководителей, создание командной работы и коммуникацию. Это гарантирует эффективное управление спортивной организацией при достижении целей организации и реализации роли организации. Результаты показали, что существует необходимость в развитии управления человеческими ресурсами в организации. Наибольшие пробелы были выявлены в сферах обучения, повышения квалификации и оплаты труда, а также выявлены недостатки в системе мотивации.

Ключевые слова: спортивная организация, человеческие ресурсы, менеджмент.

Received date 05. 10.2020

Accepted date 10.10.2020

Published date 19.10.2020 